\title{
Attitude of Organic and Inorganic Farmers on Indian Culture - A Comparative Study
}

\author{
Dr. V. Gurumoorthy \\ Senior fellow-ICSSR, Madras Institute of Development Studies, Chennai
}

\begin{abstract}
Culture is the reflection of customs, belief, knowledge, art, etc of an individual or a group living in a society. Culture was learnt or formed through socialization. It is considered as a set of knowledge passed on over time. Different cultures serves as a form of guideline or base for the behavior or code of conduct for its followers, thus in a way influenced the way of thinking and acting. Expressive forms involved in a culture like art, rituals, customs are also a representation of a particular set of people. Various civilizations from across the globe practiced or created different cultures which were passed on the next generations. Farming community in general has practiced culture involving safeguarding women, worshipping nature etc. The present study deals with the opinion of organic and inorganic farmers on Indian culture, safeguarding and protecting women, influence of western culture on youngsters and western culture penetration.
\end{abstract}

KEYWORDS: Culture, Farming Community, Inorganic Farming, Organic Farming.

\section{INTRODUCTION}

Culture is the reflection of customs, belief, knowledge, art, etc of an individual or a group living in a society. Culture was learnt or formed through socialization. It is considered as a set of knowledge passed on over time. Different cultures serves as a form of guideline or base for the behavior or code of conduct for its followers, thus in a way influenced the way of thinking and acting. Expressive forms involved in a culture like art, rituals, customs are also a representation of a particular set of people. Various civilizations from across the globe practiced or created different cultures which were passed on the next generations. Farming community in general has practiced culture involving safeguarding women, worshipping nature etc. The present study deals with the opinion of organic and inorganic farmers on Indian culture, safeguarding and protecting women, influence of western culture on youngsters and western culture penetration.

\section{OBJECTIVES OF THE STUDY}

$>$ To study the opinion of farmers on culture and its related aspects

$>$ To analyse the opinion of farmers on culture and its variables by using appropriate statistical tools

$>$ To summarize and present the results

\section{METHODOLOGY}

A well designed interview schedule was administered among the farmers. A sample of 150 organic farmers and 150 in organic farmers, ( in total 300) were surveyed, in Tamil Nadu across the five major districts. The respondents were contacted through chain-referral system by adopting snowball sampling technique and the researcher administered the interview schedule among the farmers. The collected data were classified and analyzed by using relevant statistical tools. . The socio economic factors like Age, Education and Community were taken as independent variables and analysis were made on the dependent variables such as attitude on Indian culture, Indian culture protecting women, influence of western culture on youngsters and penetration of western culture.

\section{Significant association between the Age group of Organic and inorganic farmers and Opinion on Indian Culture}

An attempt has been made to test the significant association between the age group of organic and inorganic farmers and opinion on Indian Culture, a two-way classification table with age group of organic and inorganic farmers and opinion on Indian Culture was formed. Chi-square test is applied with the null hypothesis as,

$\mathbf{H}_{\mathbf{0}}$ : There is no significant association between age group of organic and inorganic farmers and opinion on Indian Culture 


\section{International Journal of Current Science Research and Review}

ISSN: 2581-8341

Volume 04 Issue 10 October 2021

DOI: 10.47191/ijesrr/V4-i10-24, Impact Factor: 5.825

IJCSRR@ 2021

www.ijjcsrr.org

The age group wise classification of the sample organic and inorganic farmers on the basis of their opinion on Indian Culture is shown in Table.

Table. Chi-square test for significant association between age group of organic and inorganic farmers and Opinion on Indian Culture

\begin{tabular}{|c|c|c|c|c|c|c|c|c|c|}
\hline \multirow{2}{*}{$\begin{array}{l}\text { Type of } \\
\text { farmers }\end{array}$} & \multirow[t]{2}{*}{ Opinion } & \multicolumn{5}{|c|}{ Age group } & \multirow[t]{2}{*}{ Total } & \multirow{2}{*}{$\begin{array}{l}\text { Chi- } \\
\text { square } \\
\text { Value }\end{array}$} & \multirow[t]{2}{*}{ p Value } \\
\hline & & $\begin{array}{l}20-30 \\
\text { years }\end{array}$ & $\begin{array}{l}30-40 \\
\text { years }\end{array}$ & $\begin{array}{l}40-50 \\
\text { years }\end{array}$ & $\begin{array}{l}50-60 \\
\text { years }\end{array}$ & $\begin{array}{l}\text { Above } \\
60 \text { years }\end{array}$ & & & \\
\hline \multirow{6}{*}{$\begin{array}{l}\text { Organic } \\
\text { farmers }\end{array}$} & $\begin{array}{l}\text { Strongly } \\
\text { Agree }\end{array}$ & $\begin{array}{l}2 \\
(1.3)\end{array}$ & $\begin{array}{l}6 \\
(4)\end{array}$ & $\begin{array}{l}11 \\
(7.3)\end{array}$ & $\begin{array}{l}11 \\
(7.3)\end{array}$ & $\begin{array}{l}11 \\
(7.3)\end{array}$ & $\begin{array}{l}41 \\
(27.3)\end{array}$ & \multirow[t]{6}{*}{23.076} & \multirow[t]{6}{*}{0.112} \\
\hline & Agree & $\begin{array}{l}3 \\
(2)\end{array}$ & $\begin{array}{l}7 \\
(4.7)\end{array}$ & $\begin{array}{l}20 \\
(13.3)\end{array}$ & $\begin{array}{l}26 \\
(17.3)\end{array}$ & $\begin{array}{l}17 \\
(11.3)\end{array}$ & $\begin{array}{l}73 \\
(48.7)\end{array}$ & & \\
\hline & No Opinion & $\begin{array}{l}2 \\
(1.3)\end{array}$ & $\begin{array}{l}5 \\
(3.3)\end{array}$ & $\begin{array}{l}11 \\
(7.3)\end{array}$ & $\begin{array}{l}9 \\
(6)\end{array}$ & $\begin{array}{l}1 \\
(0.7)\end{array}$ & $\begin{array}{l}28 \\
(18.7)\end{array}$ & & \\
\hline & Disagree & - & $\begin{array}{l}3 \\
(2)\end{array}$ & $\begin{array}{l}1 \\
(0.7)\end{array}$ & $\begin{array}{l}1 \\
(0.7)\end{array}$ & - & $5(3.3)$ & & \\
\hline & $\begin{array}{l}\text { Strongly } \\
\text { Disagree }\end{array}$ & - & $\begin{array}{l}1 \\
(0.7)\end{array}$ & - & - & $\begin{array}{l}2 \\
(1.3)\end{array}$ & $\begin{array}{l}3 \\
(2)\end{array}$ & & \\
\hline & Total & $\begin{array}{l}7 \\
(4.7)\end{array}$ & $\begin{array}{l}22 \\
(14.7)\end{array}$ & $\begin{array}{l}43 \\
(28.7)\end{array}$ & $\begin{array}{l}47 \\
(31.3)\end{array}$ & $\begin{array}{l}31 \\
(20.7)\end{array}$ & $\begin{array}{l}150 \\
(100)\end{array}$ & & \\
\hline \multirow[t]{6}{*}{$\begin{array}{l}\text { Inorganic } \\
\text { farmers }\end{array}$} & $\begin{array}{l}\text { Strongly } \\
\text { Agree }\end{array}$ & $\begin{array}{l}1 \\
(0.7)\end{array}$ & $\begin{array}{l}7 \\
(4.7)\end{array}$ & $\begin{array}{l}11 \\
(7.3)\end{array}$ & $\begin{array}{l}10 \\
(6.7)\end{array}$ & $\begin{array}{l}11 \\
(7.3)\end{array}$ & $\begin{array}{l}40 \\
(26.7)\end{array}$ & \multirow[t]{6}{*}{14.648} & \multirow[t]{6}{*}{0.551} \\
\hline & Agree & $\begin{array}{l}4 \\
(2.7)\end{array}$ & $\begin{array}{l}10 \\
(6.7)\end{array}$ & $\begin{array}{l}24 \\
(16)\end{array}$ & $\begin{array}{l}19 \\
(12.7)\end{array}$ & $\begin{array}{l}20 \\
(13.3)\end{array}$ & $\begin{array}{l}77 \\
(51.3)\end{array}$ & & \\
\hline & No Opinion & $\begin{array}{l}2 \\
(1.3)\end{array}$ & $\begin{array}{l}5 \\
(3.3)\end{array}$ & $\begin{array}{l}7 \\
(4.7)\end{array}$ & $\begin{array}{l}9 \\
(6)\end{array}$ & $\begin{array}{l}1 \\
(0.7)\end{array}$ & $24(16)$ & & \\
\hline & Disagree & - & $\begin{array}{l}2 \\
(1.3)\end{array}$ & $\begin{array}{l}1 \\
(0.7)\end{array}$ & $\begin{array}{l}1 \\
(0.7)\end{array}$ & $\begin{array}{l}1 \\
(0.7)\end{array}$ & $\begin{array}{l}6 \\
(4)\end{array}$ & & \\
\hline & $\begin{array}{l}\text { Strongly } \\
\text { Disagree }\end{array}$ & - & - & $\begin{array}{l}1 \\
(0.7)\end{array}$ & - & $\begin{array}{l}2 \\
(1.3)\end{array}$ & $\begin{array}{l}3 \\
(2)\end{array}$ & & \\
\hline & Total & $\begin{array}{l}8 \\
(5.3)\end{array}$ & $\begin{array}{l}24 \\
(16)\end{array}$ & $\begin{array}{l}44 \\
(29.3)\end{array}$ & $\begin{array}{l}39 \\
(26)\end{array}$ & $\begin{array}{l}35 \\
(23.3)\end{array}$ & $\begin{array}{l}150 \\
(100)\end{array}$ & & \\
\hline
\end{tabular}

\section{Source: Primary data}

The age group of organic farmers' wise analysis of opinion on Indian Culture highlights that among the total 150 sample organic farmers surveyed, $26(17.3 \%)$ of the sample organic farmers who are in the age group between 40-50 years have agreed to Indian culture is better than western culture and they support to Indian culture, whereas $20(13.3 \%)$ who are in the age group between 50-60 years have agreed to Indian culture is better than western culture and 17 (11.3\%) of the sample organic farmers who are in the age group of above 60 years have agreed to Indian culture is better than western culture.

The age group of inorganic farmers' wise analysis of opinion on Indian Culture highlights that among the total 150 sample inorganic farmers surveyed, $24(16 \%)$ of the sample inorganic farmers who are in the age group between 40-50 years have agreed to Indian culture is better than western culture and they support to Indian culture, whereas 20 (13.3\%) who are in the age group of above 60 years have agreed to Indian culture is better than western culture and $19(12.7 \%)$ of the sample inorganic farmers who are in the age group between 50-60 years have agreed to Indian culture is better than western culture.

Table discloses that the calculated chi square value for Indian culture is better than western culture among different age group of sample organic and inorganic farmers is 23.076 and 14.648 which is not significant at the ' $p$ ' value of 0.112 and 0.551 . 


\section{International Journal of Current Science Research and Review}

ISSN: 2581-8341

Volume 04 Issue 10 October 2021

DOI: 10.47191/ijesrr/V4-i10-24, Impact Factor: 5.825

IJCSRR @ 2021

www.ijcsrr.org

Since the ' $p$ ' value is higher than 0.05 , the null hypothesis is accepted. It is concluded that there is no significant relationship between the age group of sample organic and inorganic farmers and Indian culture is better than western culture.

Significant association between the Educational qualification of Organic and inorganic farmers and Opinion on Indian Culture

An attempt has been made to test the significant association between the educational qualification of organic and inorganic farmers and opinion on Indian Culture, a two-way classification table with educational qualification of organic and inorganic farmers and opinion on Indian Culture was formed. Chi-square test is applied with the null hypothesis as,

$\mathbf{H}_{\mathbf{0}}$ : There is no significant association between educational qualification of organic and inorganic farmers and opinion on Indian Culture

The educational qualification wise classification of the sample organic and inorganic farmers on the basis of their opinion on Indian Culture is shown in Table.

Table. Chi-square test for significant association between Educational Qualification of Organic and Inorganic Farmers and Opinion on Indian Culture

\begin{tabular}{|c|c|c|c|c|c|c|c|c|c|}
\hline \multirow{2}{*}{$\begin{array}{l}\text { Type of } \\
\text { Farmers }\end{array}$} & \multirow[t]{2}{*}{ Opinion } & \multicolumn{5}{|c|}{ Educational Qualification } & \multirow[t]{2}{*}{ Total } & \multirow{2}{*}{$\begin{array}{l}\text { Chi-square } \\
\text { Value }\end{array}$} & \multirow{2}{*}{$\begin{array}{l}\mathbf{p} \\
\text { Value }\end{array}$} \\
\hline & & Illiterate & Primary & HSC & $\begin{array}{l}\text { Higher } \\
\text { Education }\end{array}$ & Technical & & & \\
\hline \multirow{6}{*}{$\begin{array}{l}\text { Organic } \\
\text { Farmers }\end{array}$} & $\begin{array}{l}\text { Strongly } \\
\text { Agree }\end{array}$ & $\begin{array}{l}6 \\
(4.0)\end{array}$ & $\begin{array}{l}4 \\
(2.7)\end{array}$ & $\begin{array}{l}12 \\
(8)\end{array}$ & $\begin{array}{l}16 \\
(10.7)\end{array}$ & $\begin{array}{l}3 \\
(2)\end{array}$ & $\begin{array}{l}41 \\
(27.3)\end{array}$ & \multirow[t]{5}{*}{23.844} & \multirow[t]{5}{*}{0.093} \\
\hline & Agree & $\begin{array}{l}11 \\
(7.3)\end{array}$ & $\begin{array}{l}23 \\
(15.3)\end{array}$ & $\begin{array}{l}18 \\
(12)\end{array}$ & $\begin{array}{l}17 \\
(11.3)\end{array}$ & $\begin{array}{l}4 \\
(2.7)\end{array}$ & $\begin{array}{l}73 \\
(48.7)\end{array}$ & & \\
\hline & No Opinion & $\begin{array}{l}11 \\
(7.3)\end{array}$ & $\begin{array}{l}6 \\
(4.0)\end{array}$ & $\begin{array}{l}6 \\
(4.0)\end{array}$ & $\begin{array}{l}4 \\
(2.7)\end{array}$ & $\begin{array}{l}1 \\
(0.7)\end{array}$ & $\begin{array}{l}28 \\
(18.7)\end{array}$ & & \\
\hline & Disagree & - & $\begin{array}{l}2 \\
(1.3)\end{array}$ & $\begin{array}{l}2 \\
(1.3)\end{array}$ & $\begin{array}{l}1 \\
(0.7)\end{array}$ & - & $\begin{array}{l}5 \\
(3.3)\end{array}$ & & \\
\hline & $\begin{array}{l}\text { Strongly } \\
\text { Disagree }\end{array}$ & $\begin{array}{l}1 \\
(0.7)\end{array}$ & $\begin{array}{l}2 \\
(1.3)\end{array}$ & - & - & - & $\begin{array}{l}3 \\
(2)\end{array}$ & & \\
\hline & Total & $\begin{array}{l}29 \\
(19.3)\end{array}$ & $\begin{array}{l}37 \\
(24.7)\end{array}$ & $\begin{array}{l}38 \\
(25.3)\end{array}$ & $\begin{array}{l}38 \\
(25.3)\end{array}$ & $\begin{array}{l}8 \\
(5.3)\end{array}$ & $\begin{array}{l}150 \\
(100)\end{array}$ & & \\
\hline \multirow{6}{*}{$\begin{array}{l}\text { Inorganic } \\
\text { Farmers }\end{array}$} & $\begin{array}{l}\text { Strongly } \\
\text { Agree }\end{array}$ & $\begin{array}{l}5 \\
(3.3)\end{array}$ & $\begin{array}{l}7 \\
(4.7)\end{array}$ & $\begin{array}{l}12 \\
(8)\end{array}$ & $\begin{array}{l}13 \\
(8.7)\end{array}$ & $\begin{array}{l}3 \\
(2)\end{array}$ & $\begin{array}{l}40 \\
(26.7)\end{array}$ & \multirow[t]{6}{*}{18.141} & \multirow[t]{6}{*}{0.316} \\
\hline & Agree & 10() & $\begin{array}{l}23 \\
(15.3)\end{array}$ & $\begin{array}{l}18 \\
(12)\end{array}$ & $\begin{array}{l}23 \\
(15.3)\end{array}$ & $\begin{array}{l}3 \\
(2)\end{array}$ & $\begin{array}{l}77 \\
(51.3)\end{array}$ & & \\
\hline & No Opinion & $\begin{array}{l}8 \\
(5.3)\end{array}$ & $\begin{array}{l}5 \\
(3.3)\end{array}$ & $\begin{array}{l}6 \\
(4.0)\end{array}$ & $\begin{array}{l}4 \\
(2.7)\end{array}$ & $\begin{array}{l}1 \\
(0.7)\end{array}$ & $24(16)$ & & \\
\hline & Disagree & - & $\begin{array}{l}2 \\
(1.3)\end{array}$ & $\begin{array}{l}4 \\
(2.7)\end{array}$ & & - & $\begin{array}{l}6 \\
(4)\end{array}$ & & \\
\hline & $\begin{array}{l}\text { Strongly } \\
\text { Disagree }\end{array}$ & $\begin{array}{l}1 \\
(0.7)\end{array}$ & $\begin{array}{l}1 \\
(0.7)\end{array}$ & $\begin{array}{l}1 \\
(0.7)\end{array}$ & - & - & $\begin{array}{l}3 \\
(2)\end{array}$ & & \\
\hline & Total & $\begin{array}{l}24 \\
(16)\end{array}$ & $\begin{array}{l}38 \\
(24.7)\end{array}$ & $\begin{array}{l}41 \\
(27.3)\end{array}$ & $\begin{array}{l}40 \\
(26.7)\end{array}$ & $\begin{array}{l}7 \\
(4.7)\end{array}$ & $\begin{array}{l}150 \\
(100)\end{array}$ & & \\
\hline
\end{tabular}

Source: Primary data

The educational qualification of organic farmers' wise analysis of opinion on Indian Culture highlights that among the total 150 sample organic farmers surveyed, $23(15 \%)$ of the sample organic farmers who are primary education have agreed to Indian culture is better than western culture and they support to Indian culture, whereas 18 (12\%) who are HSC qualification have 


\section{International Journal of Current Science Research and Review}

ISSN: 2581-8341

Volume 04 Issue 10 October 2021

DOI: 10.47191/ijesrr/V4-i10-24, Impact Factor: 5.825

IJCSRR@ 2021

Www.ijcsrr.org

agreed to Indian culture is better than western culture and $17(11.3 \%)$ of the sample organic farmers who are higher education have agreed to Indian culture is better than western culture.

The educational qualification of inorganic farmers' wise analysis of opinion on Indian Culture highlights that among the total 150 sample inorganic farmers surveyed, $23(15.3 \%)$ of the sample inorganic farmers who are primary education have agreed to Indian culture is better than western culture and they support to Indian culture, whereas $23(15.3 \%)$ who are higher education have agreed to Indian culture is better than western culture and $18(12 \%)$ of the sample inorganic farmers who are HSC qualification have agreed to Indian culture is better than western culture.

Table indicates that the calculated chi square value for Indian culture is better than western culture among different educational qualification of sample organic and inorganic farmers is 23.844 and 18.141 which is not significant at the ' $p$ ' value of 0.093 and 0.316 . Since the 'p' value is higher than 0.05 , the null hypothesis is accepted. It is concluded that there is no significant relationship between the educational qualification of sample organic and inorganic farmers and Indian culture is better than western culture.

\section{Significant association between the Community of Organic and inorganic farmers and Opinion on Indian Culture}

An attempt has been made to test the significant association between the community of organic and inorganic farmers and opinion on Indian Culture, a two-way classification table with community of organic and inorganic farmers and opinion on Indian Culture was formed. Chi-square test is applied with the null hypothesis as,

$\mathbf{H}_{\mathbf{0}}$ : There is no significant association between community of organic and inorganic farmers and opinion on Indian Culture

The community wise classification of the sample organic and inorganic farmers on the basis of their opinion on Indian Culture is shown in Table.

Table. Community of Organic and Inorganic Farmers and Opinion on Indian Culture

\begin{tabular}{|c|c|c|c|c|c|c|c|c|}
\hline \multirow{2}{*}{$\begin{array}{l}\text { Type of } \\
\text { Farmers }\end{array}$} & \multirow[t]{2}{*}{ Opinion } & \multicolumn{4}{|c|}{ Community } & \multirow[t]{2}{*}{ Total } & \multirow{2}{*}{$\begin{array}{l}\text { Chi-square } \\
\text { Value }\end{array}$} & \multirow[t]{2}{*}{ p Value } \\
\hline & & $\mathrm{OC}$ & $\mathrm{BC}$ & MBC & $\mathrm{SC} / \mathrm{ST}$ & & & \\
\hline \multirow{6}{*}{$\begin{array}{l}\text { Organic } \\
\text { Farmers }\end{array}$} & Strongly Agree & $\begin{array}{l}5 \\
(3.3)\end{array}$ & $\begin{array}{l}16 \\
(10.7)\end{array}$ & $\begin{array}{l}20 \\
(13.3)\end{array}$ & - & $\begin{array}{l}41 \\
(27.3)\end{array}$ & \multirow[t]{6}{*}{47.423} & \multirow[t]{6}{*}{0.000} \\
\hline & Agree & $\begin{array}{l}16 \\
(10.7)\end{array}$ & $\begin{array}{l}21 \\
(14)\end{array}$ & $\begin{array}{l}36 \\
(24)\end{array}$ & - & $\begin{array}{l}73 \\
(48.7)\end{array}$ & & \\
\hline & No Opinion & $\begin{array}{l}17 \\
(11.3)\end{array}$ & $\begin{array}{l}7 \\
(4.7)\end{array}$ & $\begin{array}{l}3 \\
(2)\end{array}$ & $\begin{array}{l}1 \\
(0.7)\end{array}$ & $\begin{array}{l}28 \\
(18.7)\end{array}$ & & \\
\hline & Disagree & - & $\begin{array}{l}1 \\
(0.7)\end{array}$ & $\begin{array}{l}3 \\
(2)\end{array}$ & $\begin{array}{l}1 \\
(0.7)\end{array}$ & $\begin{array}{l}5 \\
(3.3)\end{array}$ & & \\
\hline & $\begin{array}{l}\text { Strongly } \\
\text { Disagree }\end{array}$ & - & - & $\begin{array}{l}3 \\
(2)\end{array}$ & - & $\begin{array}{l}3 \\
(2)\end{array}$ & & \\
\hline & Total & $\begin{array}{l}38 \\
(25.3)\end{array}$ & $\begin{array}{l}45 \\
(30)\end{array}$ & $\begin{array}{l}65 \\
(43.3)\end{array}$ & $\begin{array}{l}2 \\
(1.3)\end{array}$ & $\begin{array}{l}150 \\
(100)\end{array}$ & & \\
\hline \multirow{6}{*}{$\begin{array}{l}\text { Inorganic } \\
\text { Farmers }\end{array}$} & Strongly Agree & $\begin{array}{l}6 \\
(4) \\
\end{array}$ & $\begin{array}{l}15 \\
(10) \\
\end{array}$ & $\begin{array}{l}19 \\
(12.7) \\
\end{array}$ & - & $\begin{array}{l}40 \\
(26.7)\end{array}$ & \multirow[t]{5}{*}{19.195} & \multirow[t]{5}{*}{0.084} \\
\hline & Agree & $\begin{array}{l}13 \\
(8.7)\end{array}$ & $\begin{array}{l}37 \\
(24.7)\end{array}$ & $\begin{array}{l}25 \\
(16.7)\end{array}$ & $\begin{array}{l}2 \\
(1.3)\end{array}$ & $\begin{array}{l}77 \\
(51.3)\end{array}$ & & \\
\hline & No Opinion & $\begin{array}{l}9 \\
(6)\end{array}$ & $\begin{array}{l}11 \\
(7.3)\end{array}$ & $\begin{array}{l}3 \\
(2) \\
\end{array}$ & $\begin{array}{l}1 \\
(0.7)\end{array}$ & $\begin{array}{l}24 \\
(16)\end{array}$ & & \\
\hline & Disagree & $\begin{array}{l}1 \\
(0.7)\end{array}$ & $\begin{array}{l}2 \\
(1.3)\end{array}$ & $\begin{array}{l}2 \\
(1.3)\end{array}$ & $\begin{array}{l}1 \\
(0.7)\end{array}$ & $\begin{array}{l}6 \\
(4)\end{array}$ & & \\
\hline & $\begin{array}{l}\text { Strongly } \\
\text { Disagree }\end{array}$ & $\begin{array}{l}1 \\
(0.7)\end{array}$ & - & $\begin{array}{l}2 \\
(1.3)\end{array}$ & $\begin{array}{l}3 \\
(2)\end{array}$ & $\begin{array}{l}3 \\
(2)\end{array}$ & & \\
\hline & Total & $\begin{array}{l}30 \\
(20)\end{array}$ & $\begin{array}{l}65 \\
(43.3)\end{array}$ & $\begin{array}{l}51 \\
(34)\end{array}$ & $\begin{array}{l}4 \\
(2.7)\end{array}$ & $\begin{array}{l}150 \\
(100)\end{array}$ & & \\
\hline
\end{tabular}

Source: Primary data 


\section{International Journal of Current Science Research and Review}

ISSN: 2581-8341

Volume 04 Issue 10 October 2021

DOI: 10.47191/ijcsrr/V4-i10-24, Impact Factor: 5.825

IJCSRR@ 2021

www.ijjcsrr.org

The community of organic farmers' wise analysis of opinion on Indian Culture highlights that among the total 150 sample organic farmers surveyed, $36(24 \%)$ of the sample organic farmers who belong to MBC have agreed to Indian culture is better than western culture and they support to Indian culture, whereas 21 (14\%) who belong to BC have agreed to Indian culture is better than western culture and $20(13.3 \%)$ of the sample organic farmers who belong to MBC have strongly agreed to Indian culture is better than western culture.

The community of inorganic farmers' wise analysis of opinion on Indian Culture highlights that among the total 150 sample inorganic farmers surveyed, $37(24.7 \%)$ of the sample inorganic farmers who belong to BC have agreed to Indian culture is better than western culture and they support to Indian culture, whereas $25(16.7 \%)$ who belong to MBC have agreed to Indian culture is better than western culture and 19 (12.7\%) of the sample inorganic farmers who belong to MBC have strongly agreed to Indian culture is better than western culture.

Table indicates that the calculated chi square value for Indian culture is better than western culture among different community of sample organic farmers is 47.423 which is significant at the ' $p$ ' value of 0.000 . Since the ' $p$ ' value is less than 0.05 , the null hypothesis is rejected. It is concluded that there is a significant relationship between the community of sample organic farmers and Indian culture is better than western culture.

Table further indicates that the calculated chi square value for Indian culture is better than western culture among different community of sample inorganic farmers is 19.195 which is not significant at the 'p' value of 0.084 . Since the ' $p$ ' value is higher than 0.05 , the null hypothesis is accepted. It is concluded that there is no significant relationship between the community of sample inorganic farmers and Indian culture is better than western culture.

\section{Age group of Organic and inorganic farmers and Indian culture is safeguarding and protecting the women}

In order to examine the relationship between age group of organic and inorganic farmers and Indian culture is safeguarding and protecting the women, a two way table with age group of organic and inorganic farmers and Indian culture is safeguarding and protecting the women was constructed. Accordingly, sample organic and inorganic farmers have been categorized into five groups on the basis of their age group. Chi-square test is applied with the null hypothesis as,

$\mathbf{H}_{\mathbf{0}}$ : There is no significant association between age group of organic and inorganic farmers and Indian culture is safeguarding and protecting the women

The age group wise classification of the sample organic and inorganic farmers on the basis of Indian culture is safeguarding and protecting the women is shown in Table.

Table. Chi-square test for significant association between age group of organic and inorganic farmers and Indian culture is safeguarding and protecting the women

\begin{tabular}{|c|c|c|c|c|c|c|c|c|c|}
\hline \multirow{2}{*}{$\begin{array}{l}\text { Type of } \\
\text { farmers }\end{array}$} & \multirow[t]{2}{*}{ Opinion } & \multicolumn{5}{|c|}{ Age group } & \multirow[t]{2}{*}{ Total } & \multirow{2}{*}{$\begin{array}{l}\text { Chi- } \\
\text { square } \\
\text { Value }\end{array}$} & \multirow{2}{*}{$\begin{array}{l}\mathbf{p} \\
\text { Value }\end{array}$} \\
\hline & & $\begin{array}{l}20-30 \\
\text { years }\end{array}$ & $\begin{array}{l}30-40 \\
\text { years }\end{array}$ & $\begin{array}{l}40-50 \\
\text { years }\end{array}$ & $\begin{array}{l}50-60 \\
\text { years }\end{array}$ & $\begin{array}{l}\text { Above } \\
60 \text { years }\end{array}$ & & & \\
\hline \multirow{6}{*}{$\begin{array}{l}\text { Organic } \\
\text { farmers }\end{array}$} & $\begin{array}{l}\text { Strongly } \\
\text { Agree }\end{array}$ & $\begin{array}{l}1 \\
(0.7)\end{array}$ & $\begin{array}{l}7 \\
(4.7)\end{array}$ & $\begin{array}{l}8 \\
(5.3)\end{array}$ & $\begin{array}{l}17 \\
(11.3)\end{array}$ & $\begin{array}{l}8 \\
(5.3)\end{array}$ & $\begin{array}{l}41 \\
(27.3)\end{array}$ & \multirow[t]{6}{*}{18.906} & \multirow[t]{6}{*}{0.274} \\
\hline & Agree & $\begin{array}{l}3 \\
(2)\end{array}$ & $\begin{array}{l}6 \\
(4)\end{array}$ & $\begin{array}{l}19 \\
(12.7)\end{array}$ & $\begin{array}{l}14 \\
(9.3)\end{array}$ & $\begin{array}{l}17 \\
(11.3)\end{array}$ & $\begin{array}{l}59 \\
(39.3)\end{array}$ & & \\
\hline & No Opinion & $\begin{array}{l}2 \\
(1.3)\end{array}$ & $\begin{array}{l}6 \\
(4)\end{array}$ & $\begin{array}{l}14 \\
(9.3)\end{array}$ & $\begin{array}{l}13 \\
(8.7)\end{array}$ & $\begin{array}{l}3 \\
(2)\end{array}$ & $\begin{array}{l}38 \\
(25.3)\end{array}$ & & \\
\hline & Disagree & - & $\begin{array}{l}2 \\
(1.3)\end{array}$ & $\begin{array}{l}1 \\
(0.7)\end{array}$ & $\begin{array}{l}2 \\
(1.3)\end{array}$ & $\begin{array}{l}3 \\
(2)\end{array}$ & $8(5.3)$ & & \\
\hline & $\begin{array}{l}\text { Strongly } \\
\text { Disagree }\end{array}$ & $\begin{array}{l}1 \\
(0.7)\end{array}$ & $\begin{array}{l}1 \\
(0.7)\end{array}$ & $\begin{array}{l}1 \\
(0.7)\end{array}$ & $\begin{array}{l}1 \\
(0.7)\end{array}$ & - & $4(2.7)$ & & \\
\hline & Total & $\begin{array}{l}7 \\
(4.7)\end{array}$ & $\begin{array}{l}22 \\
(14.7)\end{array}$ & $\begin{array}{l}43 \\
(28.7)\end{array}$ & $\begin{array}{l}47 \\
(31.3)\end{array}$ & $\begin{array}{l}31 \\
(20.7)\end{array}$ & $\begin{array}{l}150 \\
(100)\end{array}$ & & \\
\hline $\begin{array}{l}\text { Inorganic } \\
\text { farmers }\end{array}$ & $\begin{array}{l}\text { Strongly } \\
\text { Agree }\end{array}$ & - & $\begin{array}{l}8 \\
(5.3)\end{array}$ & $\begin{array}{l}9 \\
(6)\end{array}$ & $\begin{array}{l}9 \\
(6)\end{array}$ & $\begin{array}{l}9 \\
(6)\end{array}$ & $\begin{array}{l}35 \\
(23.3)\end{array}$ & 15.868 & 0.462 \\
\hline
\end{tabular}




\section{International Journal of Current Science Research and Review}

ISSN: 2581-8341

Volume 04 Issue 10 October 2021

DOI: 10.47191/ijesrr/V4-i10-24, Impact Factor: 5.825

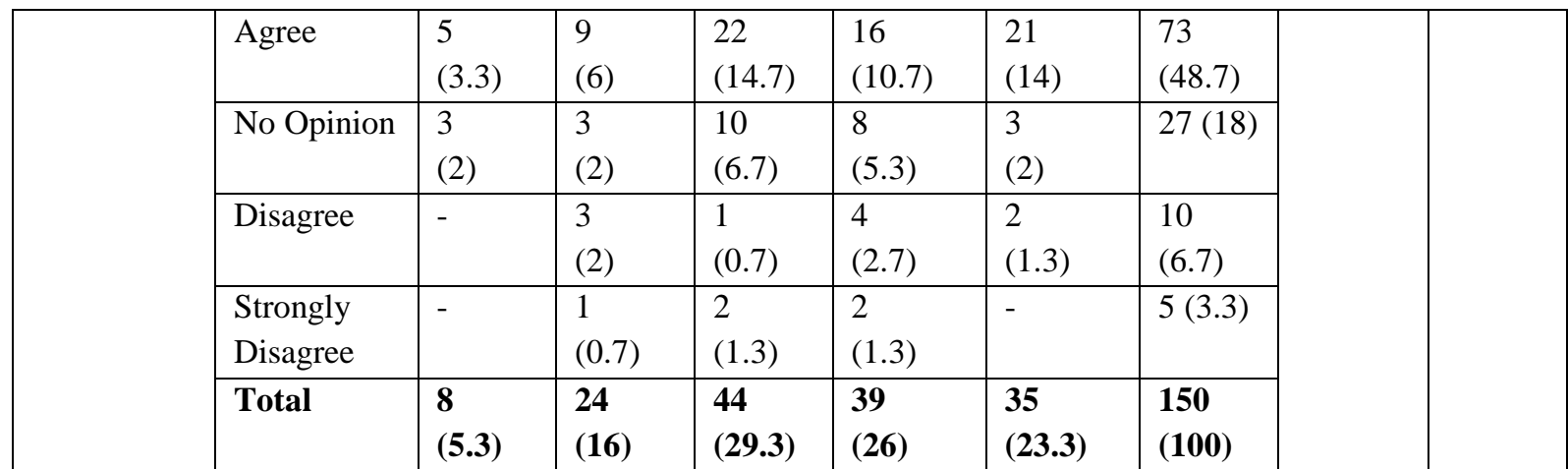

Source: Primary data

The age group of organic farmers' wise analysis of Indian culture is safeguarding and protecting the women highlights that among the total 150 sample organic farmers surveyed, 19 (12.7\%) of the sample organic farmers who are in the age group between 40-50 years have agreed to Indian culture is safeguarding and protecting the women, 17 (11.3\%) of the sample organic farmers who are in the age group of above 60 years have agreed to Indian culture is safeguarding and protecting the women and $17(11.3 \%)$ of the sample organic farmers who are in the age group between 50-60 years have strongly agreed to Indian culture is safeguarding and protecting the women.

The age group of inorganic farmers' wise analysis of Indian culture is safeguarding and protecting the women highlights that among the total 150 sample inorganic farmers surveyed, $22(14.7 \%)$ of the sample inorganic farmers who are in the age group between 40-50 years have agreed to Indian culture is safeguarding and protecting the women, 21 (14\%) of the sample inorganic farmers who are in the age group of above 60 years have agreed to Indian culture is safeguarding and protecting the women and $16(10.7 \%)$ of the sample inorganic farmers who are in the age group between 50-60 years have agreed to Indian culture is safeguarding and protecting the women.

Table discloses that the calculated chi square value for Indian culture is safeguarding and protecting the women among different age group of sample organic and inorganic farmers is 18.906 and 15.868 which is not significant at the 'p' value of 0.274 and 0.462 . Since the ' $p$ ' value is higher than 0.05 , the null hypothesis is accepted. It is concluded that there is no significant relationship between the age group of sample organic and inorganic farmers and Indian culture is safeguarding and protecting the women.

Educational qualification of Organic and inorganic farmers and Indian culture is safeguarding and protecting the women

In order to examine the relationship between educational qualification of organic and inorganic farmers and Indian culture is safeguarding and protecting the women, a two way table with educational qualification of organic and inorganic farmers and Indian culture is safeguarding and protecting the women was constructed. Chi-square test is applied with the null hypothesis as,

$\mathbf{H}_{\mathbf{0}}$ : There is no significant association between educational qualification of organic and inorganic farmers and Indian culture is safeguarding and protecting the women

The educational qualification wise classification of the sample organic and inorganic farmers on the basis of Indian culture is safeguarding and protecting the women is shown in Table.

Table. Chi-square test for significant association between Educational Qualification of Organic and Inorganic Farmers and Indian culture is safeguarding and protecting the women

\begin{tabular}{|c|c|c|c|c|c|c|c|c|c|}
\hline \multirow{2}{*}{$\begin{array}{l}\text { Type of } \\
\text { Farmers }\end{array}$} & \multirow[t]{2}{*}{ Opinion } & \multicolumn{5}{|c|}{ Educational Qualification } & \multirow[t]{2}{*}{ Total } & \multirow{2}{*}{$\begin{array}{l}\text { Chi- } \\
\text { square } \\
\text { Value }\end{array}$} & \multirow[t]{2}{*}{ p Value } \\
\hline & & Illiterate & Primary & HSC & $\begin{array}{l}\text { Higher } \\
\text { Education }\end{array}$ & $\begin{array}{l}\text { Technic } \\
\text { al }\end{array}$ & & & \\
\hline & $\begin{array}{l}\text { Strongly } \\
\text { Agree }\end{array}$ & $\begin{array}{l}7 \\
(4.7)\end{array}$ & $\begin{array}{l}7 \\
(4.7)\end{array}$ & $\begin{array}{l}12 \\
(8)\end{array}$ & $\begin{array}{l}15 \\
(10)\end{array}$ & - & $\begin{array}{l}41 \\
(27.3)\end{array}$ & 26.450 & 0.048 \\
\hline
\end{tabular}




\section{International Journal of Current Science Research and Review}

ISSN: 2581-8341

Volume 04 Issue 10 October 2021

DOI: 10.47191/ijesrr/V4-i10-24, Impact Factor: 5.825

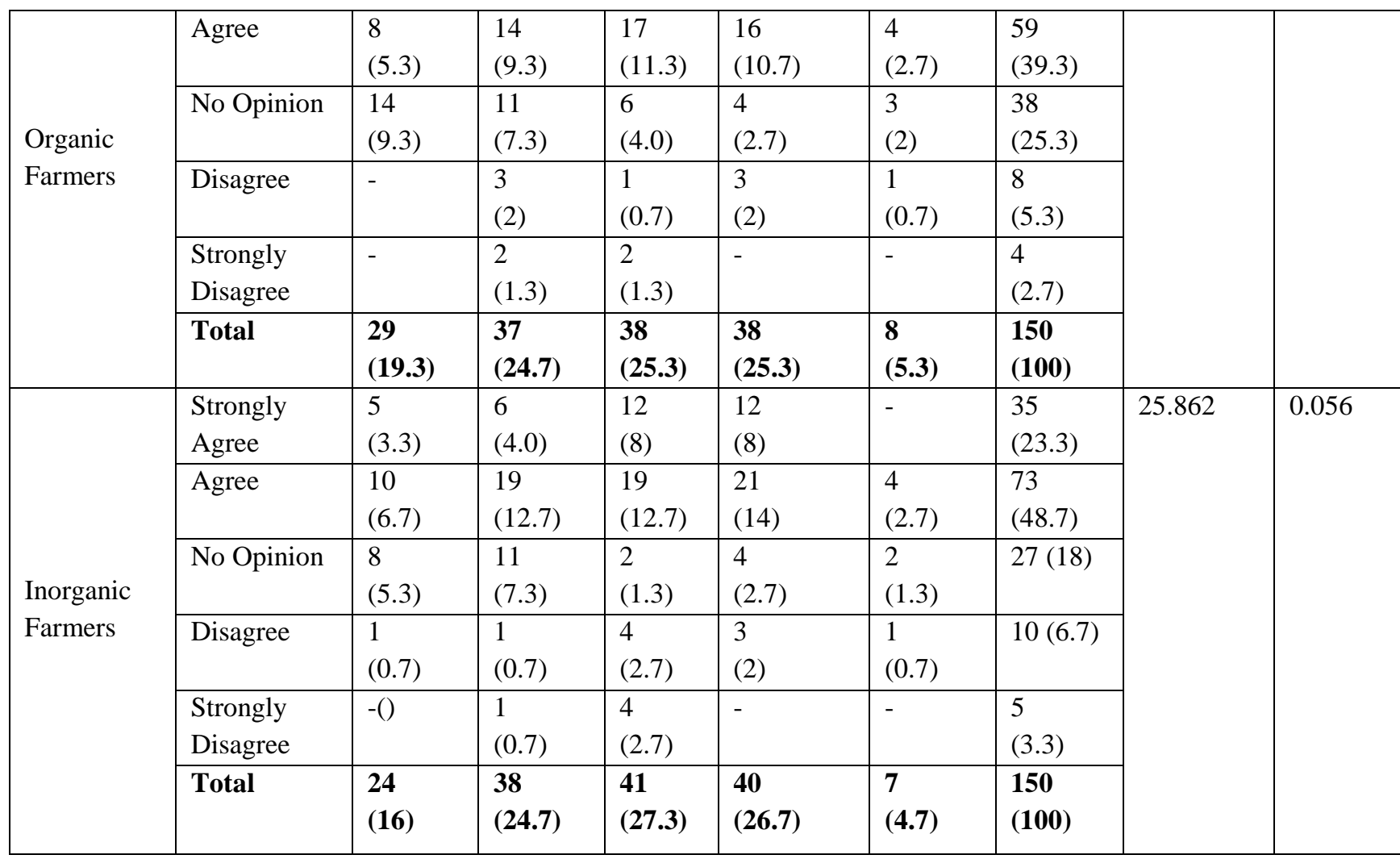

Source: Primary data

The educational qualification of organic farmers' wise analysis of Indian culture is safeguarding and protecting the women highlights that among the total 150 sample organic farmers surveyed, $17(11.3 \%)$ of the sample organic farmers who are HSC qualification have agreed to Indian culture is safeguarding and protecting the women, $16(10.7 \%)$ of the sample organic farmers who are higher education have agreed to Indian culture is safeguarding and protecting the women and 14 (9.3\%) of the sample organic farmers who are primary education have agreed to Indian culture is safeguarding and protecting the women.

The educational qualification of inorganic farmers' wise analysis of Indian culture is safeguarding and protecting the women highlights that among the total 150 sample inorganic farmers surveyed, 21 (14\%) of the sample inorganic farmers who are higher education have agreed to Indian culture is safeguarding and protecting the women, 19 (12.7\%) of the sample inorganic farmers who are HSC qualification have agreed to Indian culture is safeguarding and protecting the women and 19 (12.7\%) of the sample inorganic farmers who are primary education have agreed to Indian culture is safeguarding and protecting the women.

Table discloses that the calculated chi square value for Indian culture is safeguarding and protecting the women among different educational qualification of sample organic farmers is 26.450 which is significant at the ' $p$ ' value of 0.048 . Since the ' $p$ ' value is less than 0.05 , the null hypothesis is rejected. It is concluded that there is a significant relationship between the educational qualification of sample organic farmers and Indian culture is safeguarding and protecting the women.

Table further discloses that the calculated chi square value for Indian culture is safeguarding and protecting the women among different educational qualification of sample inorganic farmers is 25.862 which is not significant at the ' $p$ ' value of 0.056 . Since the ' $p$ ' value is higher than 0.05 , the null hypothesis is accepted. It is concluded that there is no significant relationship between the educational qualification of sample inorganic farmers and Indian culture is safeguarding and protecting the women.

Community of Organic and inorganic farmers and Indian culture is safeguarding and protecting the women

In order to examine the relationship between community of organic and inorganic farmers and Indian culture is safeguarding and protecting the women, a two way table with community of organic and inorganic farmers and Indian culture is safeguarding and protecting the women was constructed. Chi-square test is applied with the null hypothesis as, 


\section{International Journal of Current Science Research and Review}

ISSN: 2581-8341

Volume 04 Issue 10 October 2021

DOI: 10.47191/ijesrr/V4-i10-24, Impact Factor: 5.825

IJCSRR@ 2021

www.ijcsrr.org

$\mathbf{H}_{\mathbf{0}}$ : There is no significant association between community of organic and inorganic farmers and Indian culture is safeguarding and protecting the women

The community wise classification of the sample organic and inorganic farmers on the basis of Indian culture is safeguarding and protecting the women is shown in Table.

Table. Community of Organic and Inorganic Farmers and Indian culture is safeguarding and protecting the women

\begin{tabular}{|c|c|c|c|c|c|c|c|c|}
\hline \multirow{2}{*}{$\begin{array}{l}\text { Type of } \\
\text { Farmers }\end{array}$} & \multirow[t]{2}{*}{ Opinion } & \multicolumn{4}{|c|}{ Community } & \multirow[t]{2}{*}{ Total } & \multirow{2}{*}{$\begin{array}{l}\text { Chi- } \\
\text { square } \\
\text { Value }\end{array}$} & \multirow{2}{*}{$\begin{array}{l}p \\
\text { Value }\end{array}$} \\
\hline & & $\mathrm{OC}$ & $\mathrm{BC}$ & MBC & $\begin{array}{l}\mathrm{SC} / \\
\mathrm{ST}\end{array}$ & & & \\
\hline \multirow{6}{*}{$\begin{array}{l}\text { Organic } \\
\text { Farmers }\end{array}$} & Strongly Agree & $\begin{array}{l}4 \\
(2.7)\end{array}$ & $\begin{array}{l}20 \\
(13.3)\end{array}$ & $\begin{array}{l}17 \\
(11.3)\end{array}$ & - & $\begin{array}{l}41 \\
(27.3)\end{array}$ & \multirow[t]{6}{*}{53.269} & \multirow[t]{6}{*}{0.000} \\
\hline & Agree & $\begin{array}{l}13 \\
(8.7)\end{array}$ & $\begin{array}{l}14 \\
(9.3)\end{array}$ & $\begin{array}{l}32 \\
(21.3)\end{array}$ & - & $\begin{array}{l}59 \\
(39.3)\end{array}$ & & \\
\hline & No Opinion & $\begin{array}{l}20 \\
(13.3)\end{array}$ & $\begin{array}{l}10 \\
(6.7)\end{array}$ & $\begin{array}{l}7 \\
(4.7)\end{array}$ & $\begin{array}{l}1 \\
(0.7)\end{array}$ & $\begin{array}{l}38 \\
(25.3)\end{array}$ & & \\
\hline & Disagree & $\begin{array}{l}1 \\
(0.7)\end{array}$ & $\begin{array}{l}1 \\
(0.7)\end{array}$ & $\begin{array}{l}6 \\
(4)\end{array}$ & - & $8(5.3)$ & & \\
\hline & $\begin{array}{l}\text { Strongly } \\
\text { Disagree }\end{array}$ & - & - & $\begin{array}{l}3 \\
(2)\end{array}$ & $\begin{array}{l}1 \\
(0.7)\end{array}$ & $4(2.7)$ & & \\
\hline & Total & $\begin{array}{l}38 \\
(25.3)\end{array}$ & $\begin{array}{l}45 \\
(30)\end{array}$ & $\begin{array}{l}65 \\
(43.3)\end{array}$ & $\begin{array}{l}2 \\
(1.3)\end{array}$ & $\begin{array}{l}150 \\
(100)\end{array}$ & & \\
\hline \multirow{6}{*}{$\begin{array}{l}\text { Inorganic } \\
\text { Farmers }\end{array}$} & Strongly Agree & $\begin{array}{l}3 \\
(2)\end{array}$ & $\begin{array}{l}18 \\
(12)\end{array}$ & $\begin{array}{l}13 \\
(8.7)\end{array}$ & $\begin{array}{l}1 \\
(0.7)\end{array}$ & $\begin{array}{l}35 \\
(23.3)\end{array}$ & \multirow[t]{5}{*}{23.635} & \multirow[t]{6}{*}{0.023} \\
\hline & Agree & $\begin{array}{l}11 \\
(7.3)\end{array}$ & $\begin{array}{l}34 \\
(22.7)\end{array}$ & $\begin{array}{l}26 \\
(17.3)\end{array}$ & $\begin{array}{l}2 \\
(1.3)\end{array}$ & $\begin{array}{l}73 \\
(48.7)\end{array}$ & & \\
\hline & No Opinion & $\begin{array}{l}13 \\
(8.7)\end{array}$ & $\begin{array}{l}8 \\
(5.3)\end{array}$ & $\begin{array}{l}5 \\
(3.3)\end{array}$ & $\begin{array}{l}1 \\
(0.7)\end{array}$ & $27(18)$ & & \\
\hline & Disagree & $\begin{array}{l}3 \\
(2)\end{array}$ & $\begin{array}{l}4 \\
(2.7)\end{array}$ & $\begin{array}{l}3 \\
(2)\end{array}$ & - & $\begin{array}{l}10 \\
(6.7)\end{array}$ & & \\
\hline & $\begin{array}{l}\text { Strongly } \\
\text { Disagree }\end{array}$ & - & $\begin{array}{l}1 \\
(0.7)\end{array}$ & $\begin{array}{l}4 \\
(2.7)\end{array}$ & - & $5(3.3)$ & & \\
\hline & Total & $\begin{array}{l}30 \\
(20)\end{array}$ & $\begin{array}{l}65 \\
(43.3)\end{array}$ & $\begin{array}{l}51 \\
(34)\end{array}$ & $\begin{array}{l}4 \\
(2.7)\end{array}$ & $\begin{array}{l}150 \\
(100)\end{array}$ & & \\
\hline
\end{tabular}

Source: Primary data

The community of organic farmers' wise analysis of Indian culture is safeguarding and protecting the women highlights that among the total 150 sample organic farmers surveyed, $32(21.3 \%)$ of the sample organic farmers who belong to MBC have agreed to Indian culture is safeguarding and protecting the women, 20 (13.3\%) of the sample organic farmers who belong to BC have strongly agreed to Indian culture is safeguarding and protecting the women and $20(13.3 \%)$ of the sample organic farmers who belong to $\mathrm{OC}$ have no opinion to Indian culture is safeguarding and protecting the women.

The community of inorganic farmers' wise analysis of Indian culture is safeguarding and protecting the women highlights that among the total 150 sample inorganic farmers surveyed, 34 (22.7\%) of the sample inorganic farmers who belong to $\mathrm{BC}$ have agreed to Indian culture is safeguarding and protecting the women, $26(17.3 \%)$ of the sample inorganic farmers who belong to MBC have agreed to Indian culture is safeguarding and protecting the women and 18 (12\%) of the sample inorganic farmers who belong to BC have strongly agreed to Indian culture is safeguarding and protecting the women. 


\section{International Journal of Current Science Research and Review}

ISSN: 2581-8341

Volume 04 Issue 10 October 2021

DOI: 10.47191/ijcsrr/V4-i10-24, Impact Factor: 5.825

IJCSRR@ 2021

Www.ijcsrr.org

Table discloses that the calculated chi square value for Indian culture is safeguarding and protecting the women among different community of sample organic and inorganic farmers is 53.269 and 23.635 which is significant at the ' $p$ ' value of 0.000 and 0.023 . Since the ' $p$ ' value is less than 0.05 , the null hypothesis is rejected. It is concluded that there is a significant relationship between the community of sample organic and inorganic farmers and Indian culture is safeguarding and protecting the women.

\section{Significant association between the Age group of Organic and inorganic farmers and Influence of Western Culture on} Youngsters

An attempt has been made to test the significant association between the age group of organic and inorganic farmers and influence of Western Culture on Youngsters, a two-way classification table with age group of organic and inorganic farmers and influence of Western Culture on Youngsters was formed. Accordingly, sample organic and inorganic farmers have been categorized into five groups on the basis of their age group. Chi-square test is applied with the null hypothesis as,

$\mathbf{H}_{\mathbf{0}}$ : There is no significant association between age group of organic and inorganic farmers and influence of Western Culture on Youngsters

The age group wise classification of the sample organic and inorganic farmers on the basis of influence of Western Culture on Youngsters is shown in Table.

Table. Chi-square test for significant association between age group of organic and inorganic farmers and Influence of Western Culture on Youngsters

\begin{tabular}{|c|c|c|c|c|c|c|c|c|c|}
\hline \multirow{2}{*}{$\begin{array}{l}\text { Type of } \\
\text { farmers }\end{array}$} & \multirow[t]{2}{*}{ Opinion } & \multicolumn{5}{|c|}{ Age group } & \multirow[t]{2}{*}{ Total } & \multirow{2}{*}{$\begin{array}{l}\text { Chi- } \\
\text { square } \\
\text { Value }\end{array}$} & \multirow{2}{*}{$\begin{array}{l}\mathbf{p} \\
\text { Value }\end{array}$} \\
\hline & & $\begin{array}{l}20-30 \\
\text { years }\end{array}$ & $\begin{array}{l}30-40 \\
\text { years }\end{array}$ & $\begin{array}{l}40-50 \\
\text { years }\end{array}$ & $\begin{array}{l}50-60 \\
\text { years }\end{array}$ & $\begin{array}{l}\text { Above } \\
60 \text { years }\end{array}$ & & & \\
\hline \multirow{6}{*}{$\begin{array}{l}\text { Organic } \\
\text { farmers }\end{array}$} & $\begin{array}{l}\text { Strongly } \\
\text { Agree }\end{array}$ & - & $\begin{array}{l}3 \\
(2)\end{array}$ & $\begin{array}{l}7 \\
(4.7)\end{array}$ & $\begin{array}{l}7 \\
(4.7)\end{array}$ & $\begin{array}{l}8 \\
(5.3)\end{array}$ & $\begin{array}{l}25 \\
(16.7)\end{array}$ & \multirow[t]{6}{*}{15.366} & \multirow[t]{6}{*}{0.498} \\
\hline & Agree & $\begin{array}{l}4 \\
(2.7)\end{array}$ & $\begin{array}{l}9 \\
(6)\end{array}$ & $\begin{array}{l}23 \\
(15.3)\end{array}$ & $\begin{array}{l}28 \\
(18.7)\end{array}$ & $\begin{array}{l}17 \\
(11.3)\end{array}$ & $81(54)$ & & \\
\hline & No Opinion & $\begin{array}{l}3 \\
(2)\end{array}$ & $\begin{array}{l}5 \\
(3.3)\end{array}$ & $\begin{array}{l}11 \\
(7.3)\end{array}$ & $\begin{array}{l}8 \\
(5.3)\end{array}$ & $\begin{array}{l}5 \\
(3.3)\end{array}$ & $\begin{array}{l}32 \\
(21.3)\end{array}$ & & \\
\hline & Disagree & - & $\begin{array}{l}4 \\
(2.7)\end{array}$ & $\begin{array}{l}1 \\
(0.7)\end{array}$ & $\begin{array}{l}3 \\
(2)\end{array}$ & $\begin{array}{l}1 \\
(0.7)\end{array}$ & $\begin{array}{l}9 \\
(6)\end{array}$ & & \\
\hline & $\begin{array}{l}\text { Strongly } \\
\text { Disagree }\end{array}$ & - & $\begin{array}{l}1 \\
(0.7)\end{array}$ & $\begin{array}{l}1 \\
(0.7)\end{array}$ & $\begin{array}{l}1 \\
(0.7)\end{array}$ & - & $\begin{array}{l}3 \\
(2)\end{array}$ & & \\
\hline & Total & $\begin{array}{l}7 \\
(4.7)\end{array}$ & $\begin{array}{l}22 \\
(14.7)\end{array}$ & $\begin{array}{l}43 \\
(28.7)\end{array}$ & $\begin{array}{l}47 \\
(31.3)\end{array}$ & $\begin{array}{l}31 \\
(20.7)\end{array}$ & $\begin{array}{l}150 \\
(100)\end{array}$ & & \\
\hline \multirow[t]{6}{*}{$\begin{array}{l}\text { Inorganic } \\
\text { farmers }\end{array}$} & $\begin{array}{l}\text { Strongly } \\
\text { Agree }\end{array}$ & $\begin{array}{l}1 \\
(0.7)\end{array}$ & $\begin{array}{l}3 \\
(2)\end{array}$ & $\begin{array}{l}4 \\
(2.7)\end{array}$ & $\begin{array}{l}7 \\
(4.7)\end{array}$ & $\begin{array}{l}9 \\
(6)\end{array}$ & $24(16)$ & \multirow[t]{6}{*}{13.631} & \multirow[t]{6}{*}{0.626} \\
\hline & Agree & $\begin{array}{l}4 \\
(2.7)\end{array}$ & $\begin{array}{l}12 \\
(8)\end{array}$ & $\begin{array}{l}28 \\
(18.7)\end{array}$ & $\begin{array}{l}19 \\
(12.7)\end{array}$ & $\begin{array}{l}22 \\
(14.7)\end{array}$ & $\begin{array}{l}85 \\
(56.7)\end{array}$ & & \\
\hline & No Opinion & $\begin{array}{l}3 \\
(2)\end{array}$ & $\begin{array}{l}6 \\
(4)\end{array}$ & $\begin{array}{l}10 \\
(6.7)\end{array}$ & $\begin{array}{l}9 \\
(6)\end{array}$ & $\begin{array}{l}3 \\
(2)\end{array}$ & $\begin{array}{l}31 \\
(20.7)\end{array}$ & & \\
\hline & Disagree & - & $\begin{array}{l}1 \\
(0.7)\end{array}$ & $\begin{array}{l}1 \\
(0.7)\end{array}$ & $\begin{array}{l}2 \\
(1.3)\end{array}$ & $\begin{array}{l}1 \\
(0.7)\end{array}$ & $5(3.3)$ & & \\
\hline & $\begin{array}{l}\text { Strongly } \\
\text { Disagree }\end{array}$ & - & $\begin{array}{l}2 \\
(1.3)\end{array}$ & $\begin{array}{l}1 \\
(0.7)\end{array}$ & $\begin{array}{l}2 \\
(1.3)\end{array}$ & - & $5(3.3)$ & & \\
\hline & Total & $\begin{array}{l}8 \\
(5.3)\end{array}$ & $\begin{array}{l}24 \\
(16)\end{array}$ & $\begin{array}{l}44 \\
(29.3)\end{array}$ & $\begin{array}{l}39 \\
(26)\end{array}$ & $\begin{array}{l}35 \\
(23.3)\end{array}$ & $\begin{array}{l}150 \\
(100)\end{array}$ & & \\
\hline
\end{tabular}

Source: Primary data 


\section{International Journal of Current Science Research and Review}

ISSN: 2581-8341

Volume 04 Issue 10 October 2021

DOI: 10.47191/ijesrr/V4-i10-24, Impact Factor: 5.825

IJCSRR@ 2021

Www.ijcsrr.org

The age group of organic farmers' wise analysis of influence of Western Culture on Youngsters highlights that among the total 150 sample organic farmers surveyed, 28 (18.7\%) of the sample organic farmers who are in the age group between 50-60 years have agreed to influence of western culture on youngsters, whereas $23(15.3 \%)$ of the sample organic farmers who are in the age group between 40-50 years have agreed to influence of western culture on youngsters and 17 (11.3\%) of the sample organic farmers who are in the age group of above 60 years have agreed to influence of western culture on youngsters.

The age group of inorganic farmers' wise analysis of influence of Western Culture on Youngsters highlights that among the total 150 sample inorganic farmers surveyed, 28 (18.7\%) of the sample organic farmers who are in the age group between 40 50 years have agreed to influence of western culture on youngsters, whereas $22(14.7 \%)$ of the sample organic farmers who are in the age group of above 60 years have agreed to influence of western culture on youngsters and 19 (12.7\%) of the sample organic farmers who are in the age group between 50-60 years have agreed to influence of western culture on youngsters.

Table discloses that the calculated chi square value for influence of western culture on youngsters among different age group of sample organic and inorganic farmers is 15.366 and 13.631 which is not significant at the 'p' value of 0.498 and 0.626 . Since the ' $p$ ' value is higher than 0.05 , the null hypothesis is accepted. It is concluded that there is no significant relationship between the age group of sample organic and inorganic farmers and influence of western culture on youngsters.

\section{Significant association between the Educational Qualification of Organic and inorganic farmers and Influence of Western Culture on Youngsters}

An attempt has been made to test the significant association between the educational qualification of organic and inorganic farmers and influence of Western Culture on Youngsters, a two-way classification table with educational qualification of organic and inorganic farmers and influence of Western Culture on Youngsters was formed. Chi-square test is applied with the null hypothesis as,

$\mathbf{H}_{\mathbf{0}}$ : There is no significant association between educational qualification of organic and inorganic farmers and influence of Western Culture on Youngsters

The educational qualification wise classification of the sample organic and inorganic farmers on the basis of influence of Western Culture on Youngsters is shown in Table.

Table. Chi-square test for significant association between Educational Qualification of Organic and Inorganic Farmers and Influence of Western Culture on Youngsters

\begin{tabular}{|c|c|c|c|c|c|c|c|c|c|}
\hline \multirow{2}{*}{$\begin{array}{l}\text { Type of } \\
\text { Farmers }\end{array}$} & \multirow[t]{2}{*}{ Opinion } & \multicolumn{5}{|c|}{ Educational Qualification } & \multirow[t]{2}{*}{ Total } & \multirow{2}{*}{$\begin{array}{l}\text { Chi- } \\
\text { square } \\
\text { Value }\end{array}$} & \multirow[t]{2}{*}{ p Value } \\
\hline & & Illiterate & Primary & HSC & $\begin{array}{l}\text { Higher } \\
\text { Education }\end{array}$ & Technical & & & \\
\hline \multirow{6}{*}{$\begin{array}{l}\text { Organic } \\
\text { Farmers }\end{array}$} & $\begin{array}{l}\text { Strongly } \\
\text { Agree }\end{array}$ & $\begin{array}{l}1 \\
(0.7)\end{array}$ & $\begin{array}{l}3 \\
(2)\end{array}$ & $\begin{array}{l}9 \\
(6.0)\end{array}$ & $\begin{array}{l}11 \\
(7.3)\end{array}$ & $\begin{array}{l}1 \\
(0.7)\end{array}$ & $\begin{array}{l}25 \\
(16.7)\end{array}$ & \multirow[t]{6}{*}{20.861} & \multirow[t]{6}{*}{0.184} \\
\hline & Agree & $\begin{array}{l}17 \\
(11.3)\end{array}$ & $\begin{array}{l}19 \\
(12.7)\end{array}$ & $\begin{array}{l}18 \\
(12)\end{array}$ & $\begin{array}{l}22 \\
(14.7)\end{array}$ & $\begin{array}{l}5 \\
(3.3)\end{array}$ & $81(54)$ & & \\
\hline & No Opinion & $\begin{array}{l}9 \\
(6.0)\end{array}$ & $\begin{array}{l}9 \\
(6.0)\end{array}$ & $\begin{array}{l}8 \\
(5.3)\end{array}$ & $\begin{array}{l}4 \\
(2.7)\end{array}$ & $\begin{array}{l}2 \\
(1.3)\end{array}$ & $\begin{array}{l}32 \\
(21.3)\end{array}$ & & \\
\hline & Disagree & $\begin{array}{l}2 \\
(1.3)\end{array}$ & $\begin{array}{l}5 \\
(3.3)\end{array}$ & $\begin{array}{l}2 \\
(1.3)\end{array}$ & - & - & $\begin{array}{l}9 \\
(6)\end{array}$ & & \\
\hline & $\begin{array}{l}\text { Strongly } \\
\text { Disagree }\end{array}$ & - & $\begin{array}{l}1 \\
(0.7)\end{array}$ & $\begin{array}{l}1 \\
(0.7)\end{array}$ & $\begin{array}{l}1 \\
(0.7)\end{array}$ & - & $\begin{array}{l}3 \\
(2)\end{array}$ & & \\
\hline & Total & $\begin{array}{l}29 \\
(19.3)\end{array}$ & $\begin{array}{l}37 \\
(24.7)\end{array}$ & $\begin{array}{l}38 \\
(25.3)\end{array}$ & $\begin{array}{l}38 \\
(25.3)\end{array}$ & $\begin{array}{l}8 \\
(5.3)\end{array}$ & $\begin{array}{l}150 \\
(100)\end{array}$ & & \\
\hline \multirow{2}{*}{$\begin{array}{l}\text { Inorganic } \\
\text { Farmers }\end{array}$} & $\begin{array}{l}\text { Strongly } \\
\text { Agree }\end{array}$ & $\begin{array}{l}1 \\
(0.7)\end{array}$ & $\begin{array}{l}4 \\
(2.7)\end{array}$ & $\begin{array}{l}9 \\
(6.0)\end{array}$ & $\begin{array}{l}9 \\
(6.0)\end{array}$ & $\begin{array}{l}1 \\
(0.7)\end{array}$ & $24(16)$ & \multirow[t]{2}{*}{14.216} & \multirow[t]{2}{*}{0.583} \\
\hline & Agree & $\begin{array}{l}17 \\
(11.3)\end{array}$ & $\begin{array}{l}19 \\
(12.7)\end{array}$ & $\begin{array}{l}20 \\
(13.3)\end{array}$ & $\begin{array}{l}25 \\
(16.7)\end{array}$ & $\begin{array}{l}4 \\
(2.7)\end{array}$ & $\begin{array}{l}85 \\
(56.7)\end{array}$ & & \\
\hline
\end{tabular}




\section{International Journal of Current Science Research and Review}

ISSN: 2581-8341

Volume 04 Issue 10 October 2021

DOI: 10.47191/ijesrr/V4-i10-24, Impact Factor: 5.825

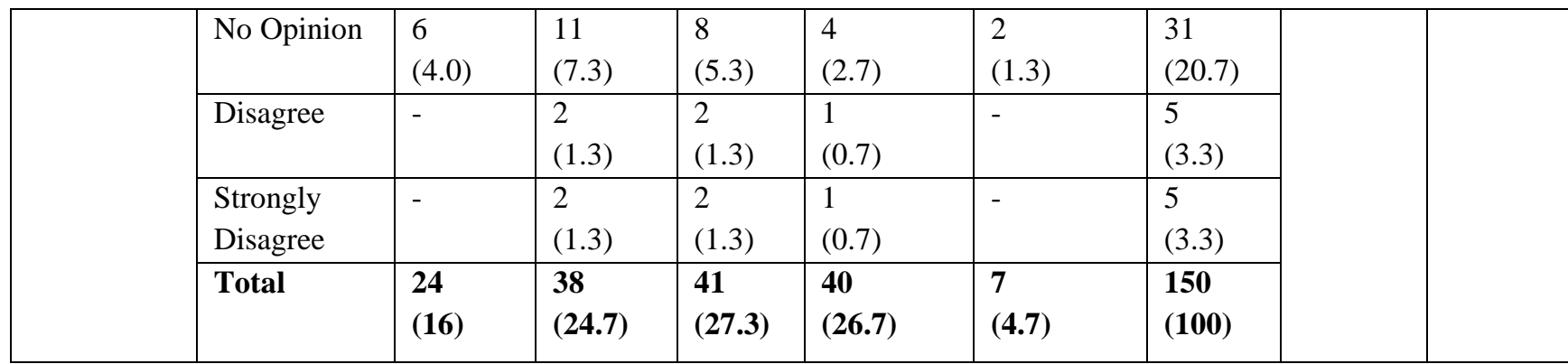

Source: Primary data

The educational qualification of organic farmers' wise analysis of influence of Western Culture on Youngsters highlights that among the total 150 sample organic farmers surveyed, $22(14.7 \%)$ of the sample organic farmers who are higher education have agreed to influence of western culture on youngsters, whereas 19 (12.7\%) of the sample organic farmers who are primary education have agreed to influence of western culture on youngsters and 18 (12\%) of the sample organic farmers who are HSC qualification have agreed to influence of western culture on youngsters.

The educational qualification of inorganic farmers' wise analysis of influence of Western Culture on Youngsters highlights that among the total 150 sample inorganic farmers surveyed, 25 (16.7\%) of the sample organic farmers who are higher education have agreed to influence of western culture on youngsters, whereas $20(13.3 \%)$ of the sample organic farmers who are HSC qualification have agreed to influence of western culture on youngsters and $19(12.7 \%)$ of the sample organic farmers who are primary education have agreed to influence of western culture on youngsters.

Table discloses that the calculated chi square value for influence of western culture on youngsters among different educational qualification of sample organic and inorganic farmers is 20.861 and 14.216 which is not significant at the 'p' value of 0.184 and 0.583 . Since the ' $p$ ' value is higher than 0.05 , the null hypothesis is accepted. It is concluded that there is no significant relationship between the educational qualification of sample organic and inorganic farmers and influence of western culture on youngsters.

Significant association between the Community of Organic and inorganic farmers and Influence of Western Culture on Youngsters

An attempt has been made to test the significant association between the community of organic and inorganic farmers and influence of Western Culture on Youngsters, a two-way classification table with community of organic and inorganic farmers and influence of Western Culture on Youngsters was formed. Chi-square test is applied with the null hypothesis as,

$\mathbf{H}_{\mathbf{0}}$ : There is no significant association between community of organic and inorganic farmers and influence of Western Culture on Youngsters

The community wise classification of the sample organic and inorganic farmers on the basis of influence of Western Culture on Youngsters is shown in Table.

Table. Community of Organic and Inorganic Farmers and Influence of Western Culture on Youngsters

\begin{tabular}{|c|c|c|c|c|c|c|c|c|}
\hline \multirow{2}{*}{$\begin{array}{l}\text { Type of } \\
\text { Farmers }\end{array}$} & \multirow[t]{2}{*}{ Opinion } & \multicolumn{4}{|c|}{ Community } & \multirow[t]{2}{*}{ Total } & \multirow{2}{*}{$\begin{array}{l}\text { Chi-square } \\
\text { Value }\end{array}$} & \multirow{2}{*}{$\begin{array}{l}\mathbf{p} \\
\text { Value }\end{array}$} \\
\hline & & $\mathrm{OC}$ & $\mathrm{BC}$ & $\mathrm{MBC}$ & SC/ST & & & \\
\hline \multirow{4}{*}{$\begin{array}{l}\text { Organic } \\
\text { Farmers }\end{array}$} & Strongly Agree & $\begin{array}{l}1 \\
(6.7)\end{array}$ & $\begin{array}{l}9 \\
(6)\end{array}$ & $\begin{array}{l}15 \\
(10)\end{array}$ & - & $\begin{array}{l}25 \\
(16.7)\end{array}$ & \multirow[t]{4}{*}{18.384} & \multirow[t]{4}{*}{0.105} \\
\hline & Agree & $\begin{array}{l}20 \\
(13.3)\end{array}$ & $\begin{array}{l}26 \\
(17.3)\end{array}$ & $\begin{array}{l}34 \\
(22.7)\end{array}$ & $\begin{array}{l}1 \\
(0.7)\end{array}$ & $81(54)$ & & \\
\hline & No Opinion & $\begin{array}{l}14 \\
(9.3)\end{array}$ & $\begin{array}{l}8 \\
(5.3)\end{array}$ & $\begin{array}{l}9 \\
(6)\end{array}$ & $\begin{array}{l}1 \\
(0.7)\end{array}$ & $\begin{array}{l}32 \\
(21.3)\end{array}$ & & \\
\hline & Disagree & $\begin{array}{l}3 \\
(2)\end{array}$ & $\begin{array}{l}2 \\
(1.7)\end{array}$ & $\begin{array}{l}4 \\
(2.7)\end{array}$ & - & $9(6)$ & & \\
\hline
\end{tabular}




\section{International Journal of Current Science Research and Review}

ISSN: 2581-8341

Volume 04 Issue 10 October 2021

DOI: 10.47191/ijesrr/V4-i10-24, Impact Factor: 5.825

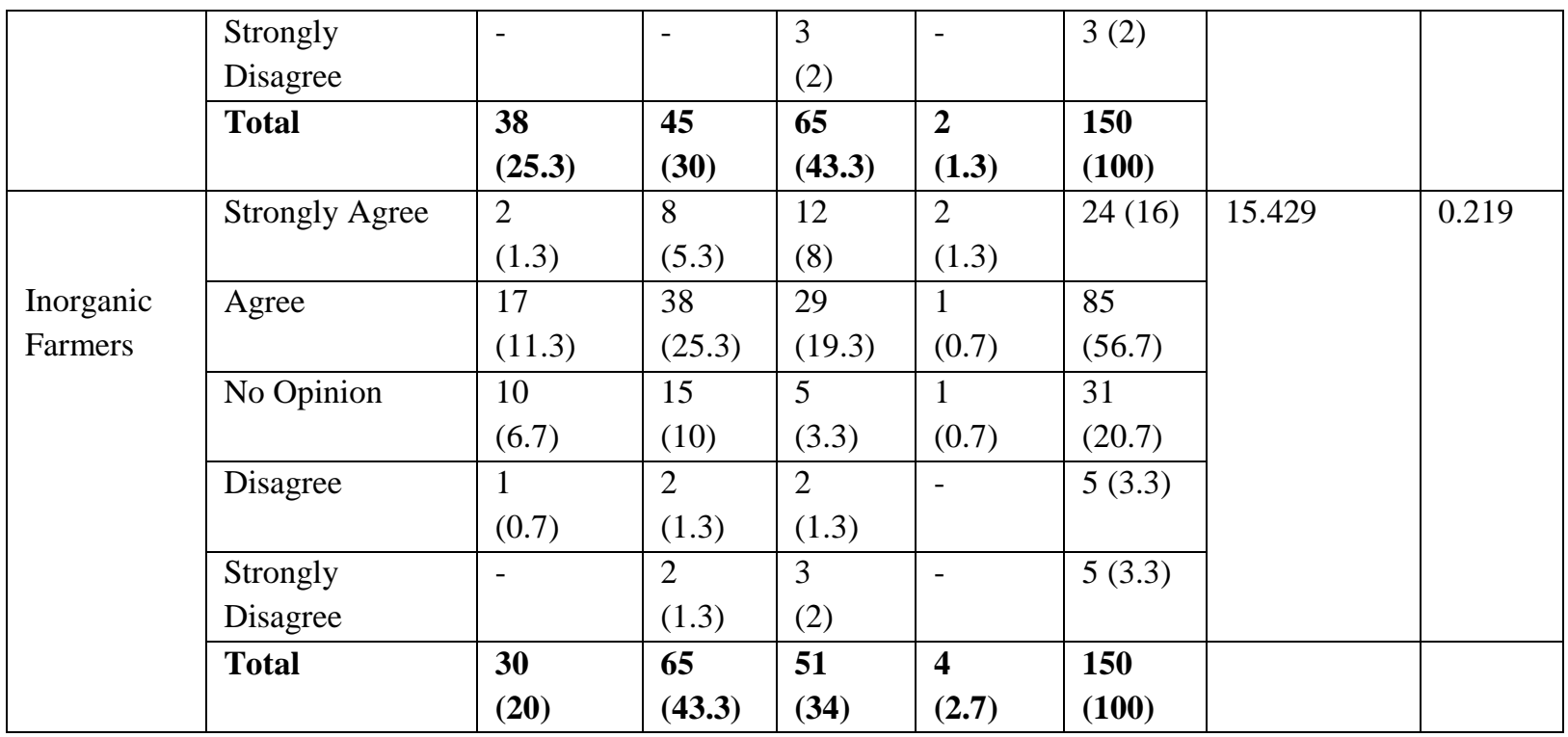

Source: Primary data

The community of organic farmers' wise analysis of influence of Western Culture on Youngsters highlights that among the total 150 sample organic farmers surveyed, 34 (22.7\%) of the sample organic farmers who belong to MBC have agreed to influence of western culture on youngsters, whereas $26(17.3 \%)$ of the sample organic farmers who belong to BC have agreed to influence of western culture on youngsters and 20 (13.3\%) of the sample organic farmers who belong to OC have agreed to influence of western culture on youngsters.

The community of inorganic farmers' wise analysis of influence of Western Culture on Youngsters highlights that among the total 150 sample inorganic farmers surveyed, 38 (25.3\%) of the sample organic farmers who belong to BC have agreed to influence of western culture on youngsters, whereas $29(19.3 \%)$ of the sample organic farmers who belong to MBC have agreed to influence of western culture on youngsters and 17 (11.3\%) of the sample organic farmers who belong to OC have agreed to influence of western culture on youngsters.

Table discloses that the calculated chi square value for influence of western culture on youngsters among different community of sample organic and inorganic farmers is 18.364 and 15.429 which is not significant at the 'p' value of 0.105 and 0.219. Since the ' $p$ ' value is higher than 0.05 , the null hypothesis is accepted. It is concluded that there is no significant relationship between the community of sample organic and inorganic farmers and influence of western culture on youngsters.

Significant association between the Age group of Organic and inorganic farmers and Western culture penetration is unavoidable

An attempt has been made to test the significant association between the age group of organic and inorganic farmers and Western culture penetration is unavoidable, a two-way classification table with age group of organic and inorganic farmers and Western culture penetration is unavoidable was formed. Chi-square test is applied with the null hypothesis as,

$\mathbf{H}_{\mathbf{0}}$ : There is no significant association between age group of organic and inorganic farmers and Western culture penetration is unavoidable

The age group wise classification of the sample organic and inorganic farmers on the basis of Western culture penetration is unavoidable is shown in Table. 


\section{International Journal of Current Science Research and Review}

ISSN: 2581-8341

Volume 04 Issue 10 October 2021

DOI: 10.47191/ijesrr/V4-i10-24, Impact Factor: 5.825

IJCSRR@ 2021

Www.ijesrr.org

Table. Chi-square test for significant association between age group of organic and inorganic farmers and Western culture penetration is unavoidable

\begin{tabular}{|c|c|c|c|c|c|c|c|c|c|}
\hline \multirow{2}{*}{$\begin{array}{l}\text { Type of } \\
\text { farmers }\end{array}$} & \multirow[t]{2}{*}{ Opinion } & \multicolumn{5}{|c|}{ Age group } & \multirow[t]{2}{*}{ Total } & \multirow{2}{*}{$\begin{array}{l}\text { Chi- } \\
\text { square } \\
\text { Value } \\
\end{array}$} & \multirow{2}{*}{$\begin{array}{l}\text { p } \\
\text { Value }\end{array}$} \\
\hline & & $\begin{array}{l}20-30 \\
\text { years }\end{array}$ & $\begin{array}{l}30-40 \\
\text { years }\end{array}$ & $\begin{array}{l}40-50 \\
\text { years }\end{array}$ & $\begin{array}{l}50-60 \\
\text { years }\end{array}$ & $\begin{array}{l}\text { Above } \\
60 \text { years }\end{array}$ & & & \\
\hline \multirow{6}{*}{$\begin{array}{l}\text { Organic } \\
\text { farmers }\end{array}$} & $\begin{array}{l}\text { Strongly } \\
\text { Agree }\end{array}$ & $\begin{array}{l}1 \\
(0.7)\end{array}$ & $\begin{array}{l}3 \\
(2)\end{array}$ & $\begin{array}{l}6 \\
(4)\end{array}$ & $\begin{array}{l}5 \\
(3.3)\end{array}$ & $\begin{array}{l}6 \\
(4)\end{array}$ & $21(14)$ & \multirow[t]{6}{*}{15.749} & \multirow[t]{6}{*}{0.471} \\
\hline & Agree & $\begin{array}{l}3 \\
(2)\end{array}$ & $\begin{array}{l}8 \\
(5.3)\end{array}$ & $\begin{array}{l}21 \\
(14)\end{array}$ & $\begin{array}{l}28 \\
(18.7)\end{array}$ & $\begin{array}{l}18 \\
(12)\end{array}$ & $78(52)$ & & \\
\hline & No Opinion & $\begin{array}{l}1 \\
(0.7)\end{array}$ & $\begin{array}{l}7 \\
(4.7)\end{array}$ & $\begin{array}{l}14 \\
(9.3)\end{array}$ & & $\begin{array}{l}4 \\
(2.7)\end{array}$ & $\begin{array}{l}35 \\
(23.3)\end{array}$ & & \\
\hline & Disagree & $\begin{array}{l}2 \\
(1.3)\end{array}$ & $\begin{array}{l}3 \\
(2)\end{array}$ & $\begin{array}{l}2 \\
(1.3)\end{array}$ & $\begin{array}{l}3 \\
(2)\end{array}$ & $\begin{array}{l}3 \\
(2)\end{array}$ & $\begin{array}{l}13 \\
(8.7)\end{array}$ & & \\
\hline & $\begin{array}{l}\text { Strongly } \\
\text { Disagree }\end{array}$ & - & $\begin{array}{l}1 \\
(0.7)\end{array}$ & - & $\begin{array}{l}2 \\
(1.3)\end{array}$ & - & $\begin{array}{l}3 \\
(2)\end{array}$ & & \\
\hline & Total & $\begin{array}{l}7 \\
(4.7)\end{array}$ & $\begin{array}{l}22 \\
(14.7)\end{array}$ & $\begin{array}{l}43 \\
(28.7)\end{array}$ & $\begin{array}{l}47 \\
(31.3)\end{array}$ & $\begin{array}{l}31 \\
(20.7)\end{array}$ & $\begin{array}{l}150 \\
(100)\end{array}$ & & \\
\hline \multirow[t]{6}{*}{$\begin{array}{l}\text { Inorganic } \\
\text { farmers }\end{array}$} & $\begin{array}{l}\text { Strongly } \\
\text { Agree }\end{array}$ & - & $\begin{array}{l}4 \\
(2.7)\end{array}$ & $\begin{array}{l}5 \\
(3.3)\end{array}$ & & $\begin{array}{l}5 \\
(3.3)\end{array}$ & $\begin{array}{l}20 \\
(13.3)\end{array}$ & \multirow[t]{6}{*}{5.343} & \multirow[t]{6}{*}{0.946} \\
\hline & Agree & $\begin{array}{l}3 \\
(2)\end{array}$ & $\begin{array}{l}13 \\
(8.7)\end{array}$ & $\begin{array}{l}23 \\
(15.3)\end{array}$ & $\begin{array}{l}20 \\
(13.3)\end{array}$ & $\begin{array}{l}20 \\
(13.3)\end{array}$ & $\begin{array}{l}79 \\
(52.7)\end{array}$ & & \\
\hline & No Opinion & $\begin{array}{l}4 \\
(2.7)\end{array}$ & $\begin{array}{l}6 \\
(4)\end{array}$ & $\begin{array}{l}13 \\
(8.7)\end{array}$ & $\begin{array}{l}11 \\
(7.3)\end{array}$ & $\begin{array}{l}7 \\
(4.7)\end{array}$ & $\begin{array}{l}41 \\
(27.3)\end{array}$ & & \\
\hline & Disagree & $\begin{array}{l}1 \\
(0.7)\end{array}$ & $\begin{array}{l}1 \\
(0.7)\end{array}$ & $\begin{array}{l}3 \\
(2)\end{array}$ & $\begin{array}{l}2 \\
(1.3)\end{array}$ & $\begin{array}{l}3 \\
(2)\end{array}$ & $\begin{array}{l}10 \\
(6.7)\end{array}$ & & \\
\hline & $\begin{array}{l}\text { Strongly } \\
\text { Disagree }\end{array}$ & - & - & - & - & - & - & & \\
\hline & Total & $\begin{array}{l}8 \\
(5.3)\end{array}$ & $\begin{array}{l}24 \\
(16)\end{array}$ & $\begin{array}{l}44 \\
(29.3)\end{array}$ & $\begin{array}{l}39 \\
(26)\end{array}$ & $\begin{array}{l}35 \\
(23.3)\end{array}$ & $\begin{array}{l}150 \\
(100)\end{array}$ & & \\
\hline
\end{tabular}

Source: Primary data

The age group of organic farmers' wise analysis of Western culture penetration is unavoidable highlights that among the total 150 sample organic farmers surveyed, 28 (18.7\%) of the sample organic farmers who are in the age group between 50-60 years have agreed to western culture penetration is unavoidable, whereas $21(14 \%)$ of the sample organic farmers who are in the age group between $40-50$ years have agreed to western culture penetration is unavoidable and 18 (12\%) of the sample organic farmers who are in the age group of above 60 years have agreed to western culture penetration is unavoidable.

Table discloses that the calculated chi square value for western culture penetration is unavoidable among different age group of sample organic and inorganic farmers is 15.749 and 5.343 which is not significant at the ' $p$ ' value of 0.471 and 0.946 . Since the ' $p$ ' value is higher than 0.05 , the null hypothesis is accepted. It is concluded that there is no significant relationship between the age group of sample organic and inorganic farmers and western culture penetration is unavoidable.

Significant association between the Educational qualification of Organic and inorganic farmers and Western culture penetration is unavoidable

An attempt has been made to test the significant association between the educational qualification of organic and inorganic farmers and Western culture penetration is unavoidable, a two-way classification table with educational qualification of organic and inorganic farmers and Western culture penetration is unavoidable was formed. Accordingly, sample organic and 


\section{International Journal of Current Science Research and Review}

ISSN: 2581-8341

Volume 04 Issue 10 October 2021

DOI: 10.47191/ijesrr/V4-i10-24, Impact Factor: 5.825

IJCSRR@ 2021

www.ijcsrr.org

inorganic farmers have been categorized into five groups on the basis of their educational qualification. Chi-square test is applied with the null hypothesis as,

$\mathbf{H}_{\mathbf{0}}$ : There is no significant association between educational qualification of organic and inorganic farmers and Western culture penetration is unavoidable

The educational qualification wise classification of the sample organic and inorganic farmers on the basis of Western culture penetration is unavoidable is shown in Table.

Table. Chi-square test for significant association between Educational Qualification of Organic and Inorganic Farmers and Western culture penetration is unavoidable

\begin{tabular}{|c|c|c|c|c|c|c|c|c|c|}
\hline \multirow{2}{*}{$\begin{array}{l}\text { Type of } \\
\text { Farmers }\end{array}$} & \multirow[t]{2}{*}{ Opinion } & \multicolumn{5}{|c|}{ Educational Qualification } & \multirow[t]{2}{*}{ Total } & \multirow{2}{*}{$\begin{array}{l}\text { Chi- } \\
\text { square } \\
\text { Value }\end{array}$} & \multirow{2}{*}{ p Value } \\
\hline & & Illiterate & Primary & HSC & $\begin{array}{l}\text { Higher } \\
\text { Education }\end{array}$ & Technical & & & \\
\hline \multirow{6}{*}{$\begin{array}{l}\text { Organic } \\
\text { Farmers }\end{array}$} & $\begin{array}{l}\text { Strongly } \\
\text { Agree }\end{array}$ & $\begin{array}{l}2 \\
(1.3)\end{array}$ & $\begin{array}{l}6 \\
(4.0)\end{array}$ & $\begin{array}{l}6 \\
(4.0)\end{array}$ & $\begin{array}{l}5 \\
(3.3)\end{array}$ & $\begin{array}{l}2 \\
(1.3)\end{array}$ & $21(14)$ & \multirow[t]{6}{*}{16.484} & \multirow[t]{6}{*}{0.420} \\
\hline & Agree & $\begin{array}{l}18 \\
(12)\end{array}$ & $\begin{array}{l}14 \\
(9.3)\end{array}$ & $\begin{array}{l}19 \\
(12.7)\end{array}$ & $\begin{array}{l}23 \\
(15.3)\end{array}$ & $\begin{array}{l}4 \\
(2.7)\end{array}$ & $78(52)$ & & \\
\hline & No Opinion & $\begin{array}{l}7 \\
(4.7)\end{array}$ & $\begin{array}{l}10 \\
(6.7)\end{array}$ & $\begin{array}{l}8 \\
(5.3)\end{array}$ & $\begin{array}{l}8 \\
(5.3)\end{array}$ & $\begin{array}{l}2 \\
(1.3)\end{array}$ & $\begin{array}{l}35 \\
(23.3)\end{array}$ & & \\
\hline & Disagree & $\begin{array}{l}2 \\
(1.3)\end{array}$ & $\begin{array}{l}4 \\
(2.7)\end{array}$ & $\begin{array}{l}5 \\
(3.3)\end{array}$ & $\begin{array}{l}2 \\
(1.3)\end{array}$ & - & $13(8.7)$ & & \\
\hline & $\begin{array}{l}\text { Strongly } \\
\text { Disagree }\end{array}$ & - & $\begin{array}{l}3 \\
(2)\end{array}$ & - & - & - & $\begin{array}{l}3 \\
(2)\end{array}$ & & \\
\hline & Total & $\begin{array}{l}29 \\
(19.3)\end{array}$ & $\begin{array}{l}37 \\
(24.7) \\
\end{array}$ & $\begin{array}{l}38 \\
(25.3) \\
\end{array}$ & $\begin{array}{l}38 \\
(25.3) \\
\end{array}$ & $\begin{array}{l}8 \\
(5.3)\end{array}$ & $\begin{array}{l}150 \\
(100)\end{array}$ & & \\
\hline \multirow{6}{*}{$\begin{array}{l}\text { Inorganic } \\
\text { Farmers }\end{array}$} & $\begin{array}{l}\text { Strongly } \\
\text { Agree }\end{array}$ & - & $\begin{array}{l}3 \\
(2)\end{array}$ & $\begin{array}{l}11 \\
(7.3)\end{array}$ & $\begin{array}{l}5 \\
(3.3)\end{array}$ & $\begin{array}{l}1 \\
(0.7)\end{array}$ & $\begin{array}{l}20 \\
(13.3)\end{array}$ & \multirow[t]{6}{*}{13.897} & \multirow[t]{6}{*}{0.307} \\
\hline & Agree & $\begin{array}{l}14 \\
(9.3)\end{array}$ & $\begin{array}{l}23 \\
(15.3)\end{array}$ & $\begin{array}{l}17 \\
(11.3)\end{array}$ & $\begin{array}{l}21 \\
(14)\end{array}$ & $\begin{array}{l}4 \\
(2.7)\end{array}$ & $\begin{array}{l}79 \\
(52.7)\end{array}$ & & \\
\hline & No Opinion & $\begin{array}{l}9 \\
(6.0)\end{array}$ & $\begin{array}{l}10 \\
(6.7)\end{array}$ & $\begin{array}{l}10 \\
(6.7)\end{array}$ & $\begin{array}{l}10 \\
(6.7)\end{array}$ & $\begin{array}{l}2 \\
(1.3)\end{array}$ & $\begin{array}{l}41 \\
(27.3)\end{array}$ & & \\
\hline & Disagree & $\begin{array}{l}1 \\
(0.7)\end{array}$ & $\begin{array}{l}2 \\
(1.3)\end{array}$ & $\begin{array}{l}3 \\
(2)\end{array}$ & $\begin{array}{l}4 \\
(2.7)\end{array}$ & - & $10(6.7)$ & & \\
\hline & $\begin{array}{l}\text { Strongly } \\
\text { Disagree }\end{array}$ & - & - & - & - & - & - & & \\
\hline & Total & $\begin{array}{l}24 \\
(16)\end{array}$ & $\begin{array}{l}38 \\
(24.7)\end{array}$ & $\begin{array}{l}41 \\
(27.3)\end{array}$ & $\begin{array}{l}40 \\
(26.7)\end{array}$ & $\begin{array}{l}7 \\
(4.7)\end{array}$ & $\begin{array}{l}150 \\
(100)\end{array}$ & & \\
\hline
\end{tabular}

\section{Source: Primary data}

The educational qualification of organic farmers' wise analysis of Western culture penetration is unavoidable highlights that among the total 150 sample organic farmers surveyed, $23(15.3 \%)$ of the sample organic farmers who are higher education have agreed to western culture penetration is unavoidable, whereas 19 (12.7\%) of the sample organic farmers who are HSC qualification have agreed to western culture penetration is unavoidable and $18(12 \%)$ of the sample organic farmers who are illiterates have agreed to western culture penetration is unavoidable.

The educational qualification of inorganic farmers' wise analysis of Western culture penetration is unavoidable highlights that among the total 150 sample inorganic farmers surveyed, 23 (15.3\%) of the sample organic farmers who are primary education have agreed to western culture penetration is unavoidable, whereas 21 (14\%) of the sample organic farmers who are 


\section{International Journal of Current Science Research and Review}

ISSN: 2581-8341

Volume 04 Issue 10 October 2021

DOI: 10.47191/ijcsrr/V4-i10-24, Impact Factor: 5.825

IJCSRR@ 2021

Www.ijcsrr.org

higher education have agreed to western culture penetration is unavoidable and $17(11.3 \%)$ of the sample organic farmers who are HSC qualification have agreed to western culture penetration is unavoidable.

Table indicates that the calculated chi square value for western culture penetration is unavoidable among different educational qualification of sample organic and inorganic farmers is 16.484 and 13.897 which is not significant at the ' $p$ ' value of 0.420 and 0.307 . Since the ' $p$ ' value is higher than 0.05 , the null hypothesis is accepted. It is concluded that there is no significant relationship between the educational qualification of sample organic and inorganic farmers and western culture penetration is unavoidable.

Significant association between the Community of Organic and inorganic farmers and Western culture penetration is unavoidable

An attempt has been made to test the significant association between the community of organic and inorganic farmers and Western culture penetration is unavoidable, a two-way classification table with community of organic and inorganic farmers and Western culture penetration is unavoidable was formed. Chi-square test is applied with the null hypothesis as,

$\mathbf{H}_{\mathbf{0}}$ : There is no significant association between community of organic and inorganic farmers and Western culture penetration is unavoidable

The community wise classification of the sample organic and inorganic farmers on the basis of Western culture penetration is unavoidable is shown in Table.

Table. Community of Organic and Inorganic Farmers and Western culture penetration is unavoidable

\begin{tabular}{|c|c|c|c|c|c|c|c|c|}
\hline \multirow{2}{*}{$\begin{array}{l}\text { Type of } \\
\text { Farmers }\end{array}$} & \multirow[t]{2}{*}{ Opinion } & \multicolumn{4}{|c|}{ Community } & \multirow[t]{2}{*}{ Total } & \multirow{2}{*}{$\begin{array}{l}\text { Chi- } \\
\text { square } \\
\text { Value }\end{array}$} & \multirow{2}{*}{$\begin{array}{l}\text { p } \\
\text { Value }\end{array}$} \\
\hline & & $\mathrm{OC}$ & $\mathrm{BC}$ & MBC & $\begin{array}{l}\mathrm{SC} / \\
\mathrm{ST}\end{array}$ & & & \\
\hline \multirow{6}{*}{$\begin{array}{l}\text { Organic } \\
\text { Farmers }\end{array}$} & Strongly Agree & $\begin{array}{l}3 \\
(2)\end{array}$ & $\begin{array}{l}7 \\
(4.7)\end{array}$ & $\begin{array}{l}10 \\
(6.7)\end{array}$ & $\begin{array}{l}1 \\
(0.7)\end{array}$ & $21(14)$ & \multirow[t]{6}{*}{23.561} & \multirow[t]{6}{*}{0.023} \\
\hline & Agree & $\begin{array}{l}18 \\
(12)\end{array}$ & $\begin{array}{l}20 \\
(13.3)\end{array}$ & $\begin{array}{l}40 \\
(26.7)\end{array}$ & - & $78(52)$ & & \\
\hline & No Opinion & $\begin{array}{l}16 \\
(10.7)\end{array}$ & $\begin{array}{l}11 \\
(7.3)\end{array}$ & $\begin{array}{l}8 \\
(5.3)\end{array}$ & - & $\begin{array}{l}35 \\
(23.3)\end{array}$ & & \\
\hline & Disagree & $\begin{array}{l}1 \\
(0.7)\end{array}$ & $\begin{array}{l}5 \\
(3.3)\end{array}$ & $\begin{array}{l}6 \\
(4)\end{array}$ & $\begin{array}{l}1 \\
(0.7)\end{array}$ & $\begin{array}{l}13 \\
(8.7)\end{array}$ & & \\
\hline & $\begin{array}{l}\text { Strongly } \\
\text { Disagree }\end{array}$ & - & $\begin{array}{l}2 \\
(1.3)\end{array}$ & $\begin{array}{l}1 \\
(0.7)\end{array}$ & - & $3(2)$ & & \\
\hline & Total & $\begin{array}{l}38 \\
(25.3)\end{array}$ & $\begin{array}{l}45 \\
(30)\end{array}$ & $\begin{array}{l}65 \\
(43.3)\end{array}$ & $\begin{array}{l}2 \\
(1.3)\end{array}$ & $\begin{array}{l}150 \\
(100)\end{array}$ & & \\
\hline \multirow{6}{*}{$\begin{array}{l}\text { Inorganic } \\
\text { Farmers }\end{array}$} & Strongly Agree & $\begin{array}{l}3 \\
(2)\end{array}$ & $\begin{array}{l}10 \\
(6.7)\end{array}$ & $\begin{array}{l}7 \\
(4.7)\end{array}$ & - & $\begin{array}{l}20 \\
(13.3)\end{array}$ & \multirow[t]{5}{*}{7.230} & \multirow[t]{6}{*}{0.613} \\
\hline & Agree & $\begin{array}{l}14 \\
(9.3)\end{array}$ & $\begin{array}{l}32 \\
(21.3)\end{array}$ & $\begin{array}{l}31 \\
(20.7)\end{array}$ & $\begin{array}{l}2 \\
(1.3)\end{array}$ & $\begin{array}{l}79 \\
(52.7)\end{array}$ & & \\
\hline & No Opinion & $\begin{array}{l}12 \\
(8)\end{array}$ & $\begin{array}{l}18 \\
(12)\end{array}$ & $\begin{array}{l}99 \\
(6)\end{array}$ & $\begin{array}{l}2 \\
(1.3)\end{array}$ & $\begin{array}{l}41 \\
(27.3)\end{array}$ & & \\
\hline & Disagree & $\begin{array}{l}1 \\
(0.7)\end{array}$ & $\begin{array}{l}5 \\
(3.3)\end{array}$ & $\begin{array}{l}4 \\
(2.7)\end{array}$ & - & $\begin{array}{l}10 \\
(6.7)\end{array}$ & & \\
\hline & $\begin{array}{l}\text { Strongly } \\
\text { Disagree }\end{array}$ & - & - & - & - & - & & \\
\hline & Total & $\begin{array}{l}30 \\
(20)\end{array}$ & $\begin{array}{l}65 \\
(43.3)\end{array}$ & $\begin{array}{l}51 \\
(34)\end{array}$ & $\begin{array}{l}4 \\
(2.7)\end{array}$ & $\begin{array}{l}150 \\
(100)\end{array}$ & & \\
\hline
\end{tabular}

Source: Primary data 


\section{International Journal of Current Science Research and Review}

ISSN: 2581-8341

Volume 04 Issue 10 October 2021

DOI: 10.47191/ijcsrr/V4-i10-24, Impact Factor: 5.825

IJCSRR@ 2021

www.ijcsrr.org

The community of organic farmers' wise analysis of Western culture penetration is unavoidable highlights that among the total 150 sample organic farmers surveyed, 40 (26.7\%) of the sample organic farmers who belong to MBC have agreed to western culture penetration is unavoidable, whereas $20(13.3 \%)$ of the sample organic farmers who belong to $\mathrm{BC}$ have agreed to western culture penetration is unavoidable and $18(12 \%)$ of the sample organic farmers who belong to OC have agreed to western culture penetration is unavoidable.

The community of inorganic farmers' wise analysis of Western culture penetration is unavoidable highlights that among the total 150 sample inorganic farmers surveyed, 32 (21.3\%) of the sample organic farmers who belong to BC have agreed to western culture penetration is unavoidable, whereas $31(20.7 \%)$ of the sample organic farmers who belong to MBC have agreed to western culture penetration is unavoidable and 14 (9.3\%) of the sample organic farmers who belong to OC have agreed to western culture penetration is unavoidable.

Table indicates that the calculated chi square value for western culture penetration is unavoidable among different community of sample organic farmers is 23.561 which is significant at the ' $p$ ' value of 0.023 . Since the ' $p$ ' value is less than 0.05 , the null hypothesis is rejected. It is concluded that there is a significant relationship between the community of sample organic farmers and western culture penetration is unavoidable.

Table further indicates that the calculated chi square value for western culture penetration is unavoidable among different community of sample inorganic farmers is 7.230 which is not significant at the 'p' value of 0.613 . Since the 'p' value is higher than 0.05 , the null hypothesis is accepted. It is concluded that there is no significant relationship between the community of sample inorganic farmers and western culture penetration is unavoidable.

\section{CONCLUSION}

The purpose of the study is to know the opinion of the farming community on the culture and its related aspects. The cultural aspects like opinion on Indian culture, safeguarding and protecting women, influence of western culture and western culture penetration were considered and analysed by comparing the selected socio economic profile of the respondents. The extensively analysed results has been presented and the results revealed that there is a considerable impact of culture on the daily lives of the farming community.

\section{REFERENCES}

1. Uchida, Y., Takemura, K., Fukushima, S., Saizen, I., Kawamura, Y., Hitokoto, H., ...\& Yoshikawa, S. (2019). Farming cultivates a community-level shared culture through collective activities: Examining contextual effects with multilevel analyses. Journal of Personality and Social Psychology, 116(1), 1.

2. Scanlan, M. (2016). The changing colors of Maple Hills: Intersections of culture, race, language, and exceptionality in a rural farming community. Journal of Cases in Educational Leadership, 19(1), 62-69.

3. Gray, I., Phillips, E., Dunn, T., Shulman, A., \& Price, R. (2000). Aspects of rural culture and the use of conservation farming. Case studies in increasing the adoption of sustainable resource management practices, 32.

Cite this Article: Dr. V. Gurumoorthy (2021). Chronic Attitude of Organic and Inorganic Farmers on Indian Culture - A Comparative Study. International Journal of Current Science Research and Review, 4(10), 1421-1436 